\title{
Coastal light pollution and marine turtles: assessing the magnitude of the problem
}

\author{
Ruth L. Kamrowski ${ }^{1, *}$, Col Limpus ${ }^{2}$, James Moloney ${ }^{1}$, Mark Hamann ${ }^{1}$ \\ ${ }^{1}$ School of Earth and Environmental Sciences, James Cook University, Townsville, Queensland 4811, Australia \\ ${ }^{2}$ Department of Environment and Heritage Protection, PO Box 2454, Brisbane, Queensland 4001, Australia
}

\begin{abstract}
Globally significant numbers of marine turtles nest on Australian beaches; however, the human population of Australia is also heavily concentrated around coastal areas. Coastal development brings with it increases in artificial light. Since turtles are vulnerable to disorientation from artificial light adjacent to nesting areas, the mitigation of disruption caused by light pollution has become an important component of marine turtle conservation strategies in Australia. However, marine turtles are faced with a multitude of anthropogenic threats and managers need to prioritise impacts to ensure limited conservation resources can result in adequate protection of turtles. Knowledge of the extent to which nesting areas may be vulnerable to light pollution is essential to guide management strategies. We use geographical information system analysis to over-lay turtle nesting data onto night-time lights data produced by the NOAA National Geophysical Data Center, to assess the proportion of marine turtles in Australia potentially at risk from light pollution. We also identify the Australian nesting sites which may face the greatest threat from artificial light. Our assessment indicates that the majority of nesting turtles appear to be at low risk, but population management units in Western Australia and Queensland are vulnerable to light pollution. The risk to turtles from light generated by industrial developments appears significantly higher than at any other location. Consequently, managers of turtle management units in regions of proposed or on-going industrial development should anticipate potentially disrupted turtle behaviour due to light pollution. Our methodology will be useful to managers of turtles elsewhere.
\end{abstract}

KEY WORDS: Artificial light · Orientation - Coastal development · GIS analysis · Vulnerability assessment

\section{INTRODUCTION}

The human population on Earth is expanding rapidly (Steck et al. 2010), and artificial light is fundamental to the functioning of modern society. Yet while humans have become accustomed to artificial cycles of light and dark, other species, especially nocturnal or crepuscular organisms, may depend upon natural light cycles for successful functioning (Kramer \& Birney 2001). As a result, the amount of artificial light now used around the world is causing some concern among scientists and conservationists (Rich \& Longcore 2006). On a global scale, the growth of human populations in coastal zones is occurring faster than human population growth in general (Nicholls 1995). Due to this disproportionate growth, coastal habitats have become some of those most vulnerable to light pollution (Bird et al. 2004).

Marine turtles are arguably the best-known example of an organism adversely affected by coastal lighting (Witherington \& Martin 2000, Salmon 2003). Dependence upon visual brightness cues for 'sea- 
finding', means the orientation of hatchling marine turtles is disrupted by artificial lighting close to the nesting beach (Witherington \& Martin 2000, Tuxbury $\&$ Salmon 2005). This can have serious negative consequences for hatchling survival. Protracted periods spent crawling on the beach increase predation risk, as well as wasting the limited energy stores hatchlings possess from their yolk, which are necessary for crucial offshore migration (Salmon 2006, Hamann et al. 2007, Booth \& Evans 2011).

Coastal lighting has also been reported to discourage adult females from nesting on particular stretches of beach (Salmon et al. 2000). Many marine turtle nesting beaches are located adjacent to human populations, or to areas earmarked for development. As human population centres expand and light levels in coastal regions around the world increase, the availability of naturally dark beaches attractive to nesting females is likely to decrease. This may lead to higher concentrations of nests on beaches deemed dark enough for nesting purposes (Salmon 2006). However, beaches with higher density nesting face a greater likelihood of nest destruction by other nesting females (Bustard \& Tognetti 1969) and potentially increased hatchling predation (Pilcher et al. 2000, Wyneken et al. 2000). In addition, shifts in nesting distribution may take hatchlings away from the oceanographic features which are most favourable for dispersal (Putman et al. 2010, Hamann et al. 2011).

Most studies concentrating on disruption to marine turtles as a result of artificial lights have been beach specific or limited to one region (e.g. Witherington 1991, Peters \& Verhoeven 1994, Salmon et al. 2000, Salmon 2003, Bertolotti \& Salmon 2005, Pendoley 2005, Stapput \& Wiltschko 2005, Harewood \& Horrocks 2008). However, the extent of artificial light usage is visible from space. Global measurements of artificial light have been collected as part of the US Air Force Defense Meteorological Satellite Program (DMSP) Operational Linescan System (OLS) since 1992 (Elvidge et al. 2007). These data are freely available from the NOAA's National Geophysical Data Center (NGDC), and consist of cloud-free composites created from multiple nightly orbits by the DMSP satellites each year (Elvidge et al. 1997, 2001). The DMSP images have been employed for a diverse range of studies in recent years (e.g. Aubrecht et al. 2008, Nagatani 2010, Badarinath et al. 2011), yet few studies have utilised these global datasets with reference to nesting turtles (but see Ziskin et al. 2008 and Salmon et al. 2000).
The wavelengths recorded by the OLS sensor are consistent with wavelengths disruptive to adult and hatchling marine turtles. Both adult and hatchling turtles have been shown to be responsive to wavelengths within the 440 to $700 \mathrm{~nm}$ range, with greatest sensitivity at longer wavelengths (approximately $580 \mathrm{~nm}$ ) for adults (Levenson et al. 2004) and from 350 to $540 \mathrm{~nm}$ for hatchlings (Witherington \& Bjorndal 1991, Witherington \& Martin 2000, Horch et al. 2008). The OLS possesses a broad spectral response from 440 to $940 \mathrm{~nm}$, making these datasets a potentially useful tool for the assessment of light pollution impacts on turtle nesting sites (Magyar 2008).

The Australian coastline supports large and globally important marine turtle nesting aggregations (Limpus 2009). However, $>80 \%$ of Australia's inhabitants live in coastal areas (Hennessy et al. 2007), and most of the current population growth, excluding capital cities, is occurring in coastal regions (Luck 2007). Currently, most beaches in northern Australia used by nesting turtles do not experience the same levels of human encroachment (and the associated impacts from light pollution) that have occurred in many other parts of the world (Chatto \& Baker 2008, Limpus 2009). However, coastal development in northern Australia is increasing. For example, the south-east portion of Queensland (QLD) and north Western Australia (WA), both of which support nesting by multiple turtle species (Limpus 2009), are each experiencing rapid urban growth and industrial development (SEQ Catchments 2010, Australian Bureau of Statistics 2012).

In Australia, all marine turtles are protected under the Australian and State Governments' conservation legislation (Limpus 2009), and the disruptive influence of light pollution is widely acknowledged (e.g. Department of Environment and Conservation 2007, 2008). Management actions considered necessary to address this issue include the identification of priority areas affected by artificial light. Yet, implementing management strategies can be expensive and time intensive (Fuentes et al. 2009). Knowledge of areas at highest risk from light pollution is important to permit management resources to be allocated most effectively (e.g. Fuentes et al. 2011).

We used the 2006 Radiance Calibrated Lights dataset from the NGDC to address 2 specific aims. Firstly, we assessed the proportion of nesting marine turtles within Australia that are exposed to coastal light pollution as it is detected from space. This proportion was assessed at both a national and 'population management unit' scale, since it is important that the severity of threats to specific population 
units is determined so as to allow targeted management approaches, thereby ensuring that conservation strategies are as effective as possible (Dobbs et al. 1999, Wallace et al. 2010). Secondly, we identified those nesting sites in Australia which may face the greatest threat from artificial light. This is the first study of its kind. The results will be beneficial for both managers and scientists, since this method allows the identification of nesting locations vulnerable to coastal light pollution at ecologically relevant scales, which can be used in combination with existing on-the-ground data to inform and guide conservation strategies or environmental impact assessments. The methods utilised in this study will also prove a useful tool for managers of marine turtles outside of Australia, in any location where limited resources require targeted conservation measures.

\section{MATERIALS AND METHODS}

\section{Study species}

Marine turtle nesting beaches occur across the entire northern coast of Australia, from northern New South Wales to Shark Bay in WA. Six of the 7 extant species of marine turtles (loggerhead Caretta caretta, green Chelonia mydas, hawksbill Eretmochelys imbricata, olive ridley Lepidochelys olivacea, flatback Natator depressus, leatherback turtles Dermochelys coriacea) nest in Australia, with only the Kemp's ridley turtle L. kempii absent. Nesting and hatchling emergence occur at different times of the year, depending on the species and population management unit (Limpus 2009). Due to the minor and sporadic nesting of leatherback turtles in Australia this species was not included in our analysis.

\section{Data acquisition}

Turtle nesting data

We extracted the locations of nesting beaches for all turtle species within Australia from the QDERM (Queensland Department of Environment and Resource Management) turtle database, September 2003. These data consisted of geographical information system (GIS) point shapefiles, with a geographic position (latitude/longitude) for each nesting beach, as well as an estimate of the number of females breeding each year at the beach. The use of adult females, excluding adult males and immature turtles, is a commonly used metric for assessing population units of marine turtles (Heppell et al. 2003). The estimates used here are the results of numerous studies (see Limpus 2009 for a review), and are the best known data available. Gaps in the database were filled using expert opinion from local government or industry turtle project staff.

\section{Population unit data}

Population genetic structures for green, loggerhead, flatback and hawksbill turtles in Australia have been extensively investigated (Bowen et al. 1992, Broderick et al. 1994, Dobbs et al. 1999, Limpus et al. 2000, Dethmers et al. 2006, Conant et al. 2009, Limpus 2009). Only 1 discrete population management unit of olive ridley turtles is currently recognised in Australia, although this is likely to evolve as more genetic research is conducted. There are numerous terms in current usage within the scientific literature to describe population units of marine turtles. We follow the terminology used by Dethmers et al. (2006), and refer to each population unit as a 'management unit'.

\section{Satellite data}

We obtained the 2006 DMSP-OLS raster image of radiance-calibrated night time light data from the NGDC archive (National Geophysical Data Centre 2006). These data were collected by Satellite F16 and are the most recent radiance-calibrated night time light products available. The DMSP satellite flies in a sun-synchronous low earth orbit $(833 \mathrm{~km}$ mean altitude), and orbits the planet 14 times each day with a broad field of view (approximately $3000 \mathrm{~km}$ swath width), allowing complete coverage of the globe to be obtained in every $24 \mathrm{~h}$ period. The OLS sensor contains a photomultiplier tube (PMT), which intensifies the visible band signal at night, and captures 30 arc second resolution grids. This grid cell size corresponds to approximately $1 \mathrm{~km}^{2}$ at the equator (Elvidge et al. 1997, Aubrecht et al. 2010). The nighttime pass occurs between 20:30 and 21:30 h each night (Elvidge et al. 2001). Turtle nesting and hatchling emergence occur throughout the night, with peak hatchling emergence occurring between 20:00 and 24:00 h (Limpus 1971, Gyuris 1993). Thus, this time period is suitable for assessing the risk to turtles from artificial lights. 


\section{Pre-assessment}

Preparation of shapefiles

The night-light data was obtained in a geographic coordinate system appropriate for global datasets (GCS_WGS_1984). Once the data pertaining to Australia had been extracted using ESRI ArcGIS 9.3.1 (Fig. 1), the data were transformed into the relevant Australian coordinate system (GCS_GDA_1994), which matched the geographic coordinate system of the nesting data. For each management unit, nightlight and turtle nesting data were then further extracted and projected into the appropriate coordinate system (GDA_1994_MGA_Zone_49 to 56).

\section{Preparation of night-light pixel data}

Pixel values within the radiance-calibrated lights product were converted into a measure of radiance $\left(\mathrm{W} \mathrm{m}^{-2} \mathrm{sr}^{-1}\right.$ ) (sr: steradian) using the conversion factor provided by the NGDC (see www.ngdc.noaa.gov/ $\mathrm{dmsp} /$ data/radcal/readme.txt). The radiance data were converted into luminance data $\left(\mathrm{cd} \mathrm{m}^{-2}\right)$ to permit a more intuitive measure of night-time light concentrations, since radiance (a radiometric unit) describes all wavelengths of light emitted by a source, whereas luminance (a photometric unit) is a measure of the electromagnetic radiation detectable by an observer (Palmer 1999).

Converting between radiance and luminance is possible, but observers are not equally sensitive to all

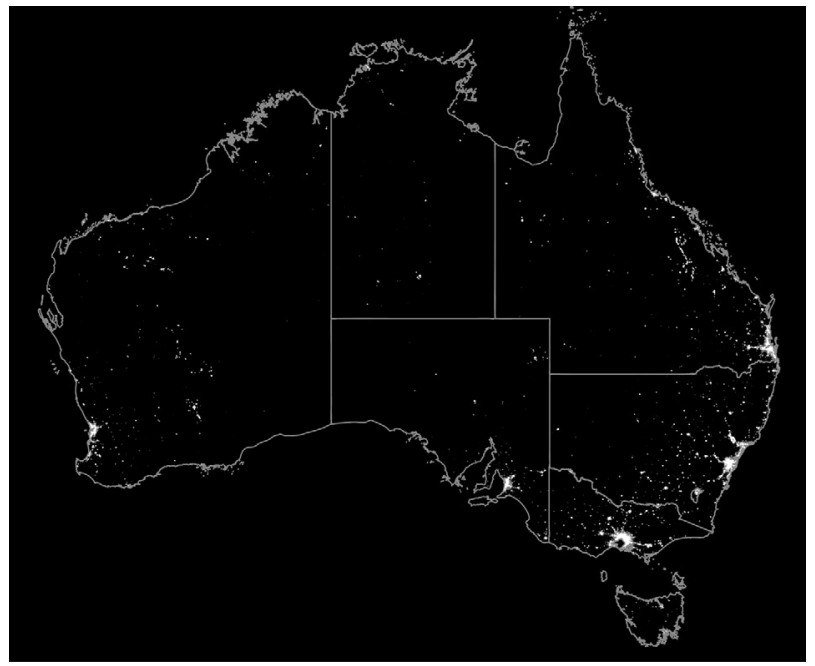

Fig. 1. Night-time lights of Australia. Image and data processing of night-light data by NOAA's National Geophysical Data Center. Defense Meteorological Satellite Program data collected by the US Air Force Weather Agency wavelengths (Narisada \& Schreuder 2004). All photometry is based on the standard visibility curve (CIE 1932) designed for the photopic (light-adapted) vision of humans (Narisada \& Schreuder 2004), which peaks at $555 \mathrm{~nm}$. The design of artificial light sources is also related to this curve, since illumination levels generated by most light sources result in light-adapted vision (Zissis et al. 2007).

Recent research has discovered that the visual sensitivity of both adult and hatchling marine turtles show similarities to human vision. Both are sensitive to wavelengths in the visible part of the spectrum, with peak sensitivity found for green wavelengths at approximately $540 \mathrm{~nm}$ in hatchlings (Horch et al. 2008) and at approximately $580 \mathrm{~nm}$ in adults (Levenson et al. 2004). At present there is no luminosity function of photopic vision available for turtles; however, given the similarities in visual sensitivity and also the wavelengths recorded by the OLS sensor, for the purposes of the present study, it was considered sufficient to convert between the units using values from the spectral luminous efficiency for human photopic vision.

Radiance values were converted into luminance values using the following equation, which represents a weighting of the radiance spectral term for each wavelength in relation to the visual response at that wavelength (Palmer 1999):

$$
X_{V}=K_{\mathrm{m}} \int_{0}^{\infty} X_{\lambda} V_{\lambda} d_{\lambda}
$$

where $X_{V}$ is the luminous intensity $\left(\mathrm{cd} \mathrm{m}^{-2}\right), K_{\mathrm{m}}$ is the constant scaling factor (683 for photopic vision; Hentschel 1994), $X_{\lambda}$ is the corresponding radiant intensity ( $\mathrm{W} \mathrm{m}^{-2} \mathrm{sr}^{-1}$, in $\left.\mathrm{nm}\right), V_{\lambda}$ is the curve for photopic vision and $\lambda$ is wavelength.

Each pixel could then be classified into a level corresponding to a ratio between artificial light and natural night-time brightness below the atmosphere (Cinzano et al. 2001a) (Table 1). Natural night-time brightness varies depending upon numerous factors, including geographical position, solar activity, time from sunset and sky area observed (Cinzano et al. 2001b). Since these details were not available for each nest site, we followed the methodology of Cinzano et al. (2001a) and used an average natural night-time brightness below the atmosphere of $2.52 \times$ $10^{-4} \mathrm{~cd} \mathrm{~m}^{-2}$ (Garstang 1986). The International Astronomical Union (IAU) recommends that night-time brightness should not be increased by $>10 \%$ (approximately $200 \times 10^{-6} \mathrm{~cd} \mathrm{~m}^{-2}$ ) as a result of artificial lighting (Smith 1979). Consequently a 10\% increase in night-sky brightness above natural levels is generally accepted as implying light pollution; this corresponds with Category 2 shown in Table 1. 
Table 1. Quantification of light pollution, using ratios according to Cinzano et al. (2001a). The categories and risk values refer to the present study

\begin{tabular}{|lcccc|}
\hline $\begin{array}{l}\text { Category } \\
\text { (risk value) }\end{array}$ & Pixel value & $\begin{array}{c}\text { Radiance value } \\
\left(\mathrm{W} \mathrm{m}^{2} \mathrm{sr}^{-1}\right)\end{array}$ & $\begin{array}{c}\text { Luminance value } \\
\left(\mathrm{cd} \mathrm{m}^{-2}\right)\end{array}$ & $\begin{array}{c}\text { Ratio over } \\
\text { natural brightness }\end{array}$ \\
\hline $1(0)$ & $0-0.6868$ & $0-1.03 \times 10^{-12}$ & $0-2.5 \times 10^{-6}$ & $0-0.01$ \\
$2(0.01)$ & $0.6868-0.7553$ & $1.03 \times 10^{-12}-1.14 \times 10^{-11}$ & $2.5 \times 10^{-6}-2.8 \times 10^{-5}$ & $0.01-0.11$ \\
$3(0.11)$ & $0.7553-0.9061$ & $1.14 \times 10^{-11}-3.43 \times 10^{-11}$ & $2.8 \times 10^{-5}-8.3 \times 10^{-5}$ & $0.11-0.33$ \\
$4(0.33)$ & $0.9061-1.36$ & $3.43 \times 10^{-11}-1.03 \times 10^{-10}$ & $8.3 \times 10^{-5}-2.5 \times 10^{-4}$ & $0.33-1$ \\
$5(1)$ & $1.36-2.734$ & $1.03 \times 10^{-10}-3.11 \times 10^{-10}$ & $2.5 \times 10^{-4}-7.6 \times 10^{-4}$ & $1-3$ \\
$6(3)$ & $2.734-6.842$ & $3.11 \times 10^{-10}-9.34 \times 10^{-10}$ & $7.6 \times 10^{-4}-2.3 \times 10^{-3}$ & $3-9$ \\
$7(9)$ & $6.842-19.167$ & $9.34 \times 10^{-10}-2 \times 10^{-9}$ & $2.3 \times 10^{-3}-6.8 \times 10^{-3}$ & $9-27$ \\
$8(27)$ & $>19.167$ & $>2 \times 10^{-9}$ & $>6.8 \times 10^{-3}$ & $>27$ \\
\hline
\end{tabular}

How bright a light appears to a turtle depends on several spectral characteristics of the light, i.e. light intensity, wavelength and turtle spectral sensitivity (Pendoley 2005). Marine turtle hatchlings are sensitive to very low light intensities across the visible spectrum (Witherington \& Bjorndal 1991), but particularly between violet and green wavelengths (400 to $500 \mathrm{~nm}$ ). Since the satellite data we used include wavelengths within this range, we reasonably assume that light levels categorised as 'light pollution' in the present study are visible to turtles. Moreover, given that very little light is necessary to disrupt the orientation of hatchlings (Witherington \& Martin 2000), we believe that the threshold of light pollution utilised here is relevant to turtles.

\section{Analysis of light proximity to nesting locations}

Nesting beach sites for each species were overlaid onto the night-light images, and a buffer was drawn around each nesting site. The data collected by the DMSP sensors corresponded to an area greater than that of actual light sources on the ground (Rodrigues et al. 2012) due to the phenomenon of 'skyglow', which refers to the dome of light projected upwards and outwards from urban areas at night (Chalkias et al. 2006). Skyglow is considered to contribute significantly to ecological impacts from light pollution (Rich \& Longcore 2006, Kyba et al. 2011). For example, light generated by an aluminium refinery in QLD, Australia, disrupted marine turtle orientation $18 \mathrm{~km}$ away (Hodge et al. 2007). Consequently, to take potential effects of skyglow from urban areas into account, but allowing for small location inaccuracies in overlaying transformed and projected data layers, we followed the methodology used by Aubrecht et al. (2008) and used a buffer with a radius of $25 \mathrm{~km}$.
Given the low spatial resolution of the night-time light data (Elvidge et al. 1997), as well as other factors which may influence the impact of artificial lights close to nesting beaches, such as barriers, cloud cover and moon phase (Salmon \& Witherington 1995, Witherington \& Martin 2000, Kyba et al. 2011), 2 measures were used to estimate the potential risk of light pollution faced by each species of nesting turtle-as a means of avoiding false precision. The buffer (25 $\mathrm{km}$ radius) surrounding each nest site encompassed approximately 2400 pixels, each of which possessed a value corresponding to the amount of light emitted in that area. The mean and maximum pixel values within each buffer were calculated using the zonal statistics tool and Hawth's Tools extension (Beyer 2004) in ArcGIS. These values were then assigned into one of the light pollution categories (as per Cinzano et al. 2001a) using the values given in Table 1. This gave 2 potential risk values for each site: 'mean light exposure' calculated from the mean pixel value and 'maximum light exposure' calculated from the maximum pixel value. Using the maximum pixel value provides an indication of the highest amount of light potentially visible to turtles at each site, and as such is the high-risk scenario. The mean pixel value was calculated across the entire area encompassed by each buffer, to effectively 'smooth out' the amount of artificial light emitted in that area (since light levels will be highest in areas where bright lights are located, decreasing as distance from the light source increases), hence providing a diffuse measure of light pollution within a particular buffer area. This was used to provide a secondary measure of risk given that nesting turtles may not be directly exposed to the highest levels of light present in the immediate area, but would still likely be susceptible to skyglow effects.

Next, to determine the sites potentially at highest risk from light pollution for each species and man- 
agement unit, we calculated the percentage nesting that occurred at each nesting location, both nationally and within each management unit. Then we weighted each site for potential risk, by multiplying the percentage nesting by the mean and maximum light exposure risk values, to give 2 potential measures of exposure to light pollution (presented as median values \pm standard deviations).

\section{Data analysis}

Data were tested for normality using the Kolmogorov-Smirnoff test. Since data were not found to be normally distributed, comparisons of light exposure between population management units were assessed using the Mann-Whitney $U$-test and the Kruskall-Wallis test. Post hoc pairwise comparisons of the latter were carried out using Dunn-Bonferroni tests (Dunn 1964). All data were analysed using IBM SPSS 20 statistical software.

\section{RESULTS}

\section{National light pollution exposure}

Nesting sites for loggerhead, green, hawksbill and flatback turtles in Australia appear to be exposed to varying degrees of light pollution (Table 2). However, despite the broad geographic scale of impact, the majority of marine turtle nesting sites in Australia appear minimally affected by either level of light pollution exposure (Table 2).

\section{Management unit light pollution exposure}

The above analysis was repeated with the species nesting site data merged into management units (Bowen et al. 1992, Broderick et al. 1994, Dobbs et al. 1999, Limpus et al. 2000, Dethmers et al. 2006, Limpus 2009, Wallace et al. 2010).

\section{Loggerheads}

There are 2 management units of loggerheads in Australia: the WA management unit, which occurs from Dirk Hartog Island to the Muiron Island region, and the eastern Australian management unit, which is concentrated on the mainland coast of southeast QLD, the islands in the southern Great Barrier Reef (GBR) and minor nesting sites in New Caledonia and Vanuatu (Limpus 2009).

Using the maximum light exposure values, we found more than a third of nesting WA loggerheads and $43.9 \%$ of the eastern Australian loggerheads were potentially exposed to light pollution (Table 3). Indeed a maximum light pollution weighting of 461.54 occurred for WA loggerheads (307.7 \pm 217.6$)$, which is significantly higher than the maximum weighted exposure for eastern Australian loggerheads $(\max .=80.6$; median $=8.06 \pm 31.76$; MannWhitney $\left.U=<1, \mathrm{n}_{1}=2, \mathrm{n}_{2}=30, \mathrm{p}<0.05\right)$.

However, when using the mean light exposure values, we found that, although the WA loggerheads appeared relatively unaffected by light pollution, $22 \%$ of the nesting sites for the eastern Australian management unit had a light pollution exposure

Table 2. Proportion of nesting in Australia, by each species, potentially at risk from each category of light pollution, using the mean (mean light exposure) and maximum (maximum light exposure) pixel values from the radiance calibrated light data within a $25 \mathrm{~km}$ radius buffer surrounding each nest site. Cc: loggerhead Caretta caretta; Cm: green Chelonia mydas; Ei: hawksbill Eretmochelys imbricata; Lo: olive ridley Lepidochelys olivacea. Nd: flatback Natator depressus

\begin{tabular}{|c|c|c|c|c|c|c|c|c|c|c|c|}
\hline \multirow{2}{*}{$\begin{array}{l}\text { Ratio over } \\
\text { natural } \\
\text { brightness }\end{array}$} & \multirow{2}{*}{$\begin{array}{c}\text { Light } \\
\text { pollution } \\
\text { category }\end{array}$} & \multicolumn{2}{|c|}{$-\mathrm{Cc}-$} & \multicolumn{2}{|c|}{$-\mathrm{Cm}$} & \multicolumn{2}{|c|}{$\begin{array}{l}\text { roportion nesting (\%) } \\
\quad \mathrm{Ei}-\end{array}$} & \multicolumn{2}{|c|}{ Lo } & \multicolumn{2}{|c|}{$-\mathrm{Nd}$} \\
\hline & & Max. & Mean & Max. & Mean & Max. & Mean & Max. & Mean & Max. & Mean \\
\hline $0-0.01$ & 1 & 61.08 & 89.5 & 73.81 & 85.35 & 35.58 & 74.44 & 90.25 & 100 & 32.09 & 75.93 \\
\hline $0.01-0.11$ & 2 & 0 & 0 & 0 & 0 & 0 & 0 & 0 & 0 & 0 & 0.02 \\
\hline $0.11-0.33$ & 3 & 0 & 0 & 0 & 0.05 & 0 & 0 & 0 & 0 & 0 & 0.16 \\
\hline $0.33-1$ & 4 & 0 & 0.29 & 0 & 2.71 & 0 & 0.35 & 0 & 0 & 0 & 21.07 \\
\hline $1-3$ & 5 & 0 & 0.29 & 0 & 11.79 & 0 & 25.22 & 0 & 0 & 0 & 1.21 \\
\hline $3-9$ & 6 & 9.04 & 9.33 & 0.48 & 0.07 & 4.87 & 0 & 9.3 & 0 & 3.39 & 1.56 \\
\hline $9-27$ & 7 & 9.18 & 0.58 & 2.86 & 0.005 & 12.88 & 0 & 0.45 & 0 & 19.1 & 0.06 \\
\hline$>27$ & 8 & 20.7 & 0 & 22.85 & 0 & 46.67 & 0 & 0 & 0 & 45.42 & 0 \\
\hline \multicolumn{2}{|c|}{$\begin{array}{l}\text { Total \% exposed to } \\
\text { light pollution }\end{array}$} & 38.92 & 10.5 & 26.19 & 14.65 & 64.42 & 25.56 & 9.75 & 0 & 67.91 & 24.07 \\
\hline
\end{tabular}


Table 3. Proportion of each population management unit of marine turtles in Australia located in nesting areas potentially exposed to artificial lights brighter than the threshold level of light pollution, i.e. light exposure of Category 2 or above (see Table 1). GBR: Great Barrier Reef

\begin{tabular}{|c|c|c|c|}
\hline Turtle species & $\begin{array}{c}\text { Population } \\
\text { management unit }\end{array}$ & $\begin{array}{c}\text { Risk from mean } \\
\text { light exposure } \\
\text { (\%, using mean pixel value) }\end{array}$ & $\begin{array}{c}\text { Risk from maximum } \\
\text { light exposure } \\
\text { (\%, using max. pixel value) }\end{array}$ \\
\hline \multirow[t]{2}{*}{ Loggerhead } & Western Australia & 0 & 34.2 \\
\hline & Eastern Australia & 21.5 & 43.9 \\
\hline \multirow[t]{7}{*}{ Green } & North West Shelf & 39 & 68.3 \\
\hline & Scott Reef & 0 & 0 \\
\hline & Ashmore Reef & 0 & 0 \\
\hline & Gulf of Carpentaria & 0 & 4.5 \\
\hline & Northern GBR & $<1$ & $<1$ \\
\hline & Coral Sea & 0 & 0 \\
\hline & Southern GBR & 2.2 & 3.8 \\
\hline \multirow[t]{3}{*}{ Hawksbill } & Western Australia & 54.5 & 99.8 \\
\hline & Gulf of Carpentaria & 3.5 & 41.5 \\
\hline & Northern GBR \& Torres Strait & 0 & 31.4 \\
\hline Olive ridley & Northern Australia & 0 & 9.8 \\
\hline \multirow[t]{4}{*}{ Flatback } & North West Shelf & 59.06 & 87.4 \\
\hline & Western Northern Territory & 0 & 0 \\
\hline & Gulf of Carpentaria \& Torres Strait & $<1$ & 61 \\
\hline & Eastern Australia & 24.2 & 50.1 \\
\hline
\end{tabular}

weighting of $8.96(2.7 \pm 3.84)$; thus the sites are potentially at risk from light pollution (Table 3 ).

\section{Greens}

There are 7 recognised green turtles management units in Australia (Dethmers et al. 2006). Only a small percentage of nesting sites for 3 of the management units were determined to be potentially at risk from light pollution (Table 3). The exception to this was the North West Shelf management unit in WA, which showed a large proportion of nesting sites potentially at risk from both levels of light exposure (39\% of the North West Shelf green turtle nesting areas highlighted using the mean light exposure values, and $68 \%$, using the maximum light exposure values).

There was a statistically significant difference between the maximum light exposure of the 3 green turtle management units indicated as exposed to light pollution (Kruskal-Wallis $\chi^{2}[3, \mathrm{~N}=40]=23.07$, $\mathrm{p}<0.01$ ). Pair-wise comparisons indicated that risk of light pollution for nesting turtles on the North West Shelf $(658.54 ; 197.6 \pm 196.03)$ was significantly higher than for all other green turtle management units. Also, in eastern Australia, the risk of light pollution for green turtles nesting in the southern GBR stock $(16.93 ; 1.69 \pm 6.96)$ was significantly higher than for the northern GBR stock $(0.33 ; 0.22$ $\pm 0.15)$.
Using the mean light exposure values, green turtles nesting in the North West Shelf $(24.39 ; 0 \pm 8.1)$ are exposed to a significantly higher potential risk from light pollution compared to green turtles in the GBR (northern GBR: $0.11 ; 0.07 \pm 0.05$; southern GBR: $1.88 ; 0.19 \pm 0.62$ ) (Kruskal-Wallis $\chi^{2}[2, N=13]=7.67$, $\mathrm{p}<0.01)$.

\section{Hawksbills}

Three hawksbill turtle management units are recognised in Australia (Broderick et al. 1994, Dobbs et al. 1999, Limpus et al. 2000). Using the maximum light exposure values, a large proportion of all 3 were potentially exposed to light pollution (Table 3). Most notable was hawksbill nesting in WA, for which $99.8 \%$ of nesting appeared to be exposed. The maximum light pollution weighting for hawksbills in WA $(1225.42 ; 673.98 \pm 636.75)$ was significantly higher than for hawksbills in the Gulf of Carpentaria (53.05; $17.68 \pm 18.12$ ), and for hawksbills in the Torres Strait and northern GBR $(84.59 ; 0.85 \pm 21.99)$ (KruskalWallis $\chi^{2}[2, \mathrm{~N}=46]=23.88, \mathrm{p}<0.01$ ).

When employing the mean light exposure values, a large proportion of hawksbill nesting in WA remained highlighted as being at potential risk from light pollution, with an exposure weighting of 45.39 (4.54 \pm 23.58), but the other management units were not determined to be at significant potential risk. The small 
sample size of affected sites precluded statistical analysis, but the medians indicated that the WA management unit remains at higher risk from light pollution than hawksbills nesting in northern Australia.

\section{Olive ridleys}

There is currently only 1 recognised management unit of olive ridley turtles in Australia (Limpus 2009). The nesting sites for this management unit appeared relatively unaffected by light pollution. The mean light exposure values indicated that none of the nesting sites appeared to be exposed to light pollution, and, using the maximum light exposure values, only 4 out of 25 nesting sites (9.8\% of nesting olive ridleys) were potentially exposed to light pollution of Categories 6 and 7 (Table 2).

\section{Flatbacks}

Four flatback turtle management units are currently recognised in Australia (Limpus 2009), although with on-going genetic research this is likely to evolve over time. Flatback turtles which nest in the western Northern Territory appeared largely unexposed to light pollution (Table 3). However, for the other 3 management units when using the maximum light exposure values, large nesting proportions appeared potentially at risk from light pollution, whereas only the North West Shelf and eastern Australia management units were identified to be at potential risk when employing the mean light exposure values.

The maximum light exposure values gave a maximum weighting of 637.8 for flatback turtles on the North West Shelf $(330 \pm 294.3)$. This was significantly

Table 4. The 3 marine turtle management units in Australia potentially most exposed to light pollution, using the mean (mean light exposure) and maximum (maximum light exposure) pixel values

\begin{tabular}{|lcc|}
\hline $\begin{array}{c}\text { Population } \\
\text { management } \\
\text { units }\end{array}$ & $\begin{array}{c}\text { Mean light } \\
\text { exposure }\end{array}$ & $\begin{array}{c}\text { Max. light } \\
\text { exposure }\end{array}$ \\
\hline 1 & $\begin{array}{c}\text { North West Shelf } \\
\text { flatback turtles } \\
\text { Western Australian } \\
\text { hawksbill turtles } \\
\text { North West Shelf } \\
\text { green turtles }\end{array}$ & $\begin{array}{c}\text { Western Australian } \\
\text { hawksbill turtles } \\
\text { North West Shelf } \\
\text { North West Shelf } \\
\text { green turtles }\end{array}$ \\
\hline
\end{tabular}

higher than exposure weightings obtained for flatback turtles nesting in either the Gulf of Carpentaria and Torres Strait $(97.69 ; 1.51 \pm 13.58)$ or eastern Australia $(94.57 ; 4.73 \pm 23)$. Eastern Australian sites appeared significantly more light-exposed than Gulf of Carpentaria and Torres Strait sites (Kruskal-Wallis $\left.\chi^{2}[2, \mathrm{~N}=115]=49.58, \mathrm{p}<0.01\right)$.

When using the mean light exposure values, flatback nesting sites on the North West Shelf appeared to be exposed to significantly more light pollution $(23.62 ; 4.78 \pm 9.46)$ than sites in eastern Australia $(5.25 ; 0.53 \pm 1.98)$ (Mann-Whitney $U=16, \mathrm{n}_{1}=4, \mathrm{n}_{2}=$ $39, \mathrm{p}<0.01)$.

\section{Region}

For each species with multiple management units within Australia, it was the management units nesting in WA that were exposed to the highest levels of light pollution (Table 4). In particular the Dampier Archipelago, Barrow Island, Montebello Islands and Cape Range Ningaloo were identified as potential high-risk nesting sites for $>1$ species (Figs. $2 \& 3$ ).

\section{DISCUSSION}

Marine turtles spend $100 \%$ of their critical breeding life-history phase (egg laying, incubation and hatchling emergence) out of the water on beaches. Moreover, turtles migrate from dispersed foraging grounds to aggregate at these breeding sites (e.g. Limpus et al. 1992). Thus, effective, long-term conservation strategies require the protection of these developmental habitats (Troëng \& Rankin 2005). Since successful turtle nesting is strongly hindered by the presence of artificial light (Witherington \& Martin 2000) and the effective management of light pollution adjacent to turtle nesting sites may be both expensive and time-intensive (e.g. Fuentes et al. 2009), the identification of nesting sites at greatest risk from light pollution is crucial to ensure that limited conservation resources are allocated most effectively (e.g. Fuentes et al. 2011).

We used satellite imaging as a broad-scale tool for the identification and comparison of nesting locations potentially vulnerable to coastal light pollution at ecologically relevant scales. An important caveat to our study, given the coarse spatial scale of the dataset utilized, is that beachfront lighting in an otherwise undeveloped area may not register in the satellite data, but would retain the potential to disrupt turtle 


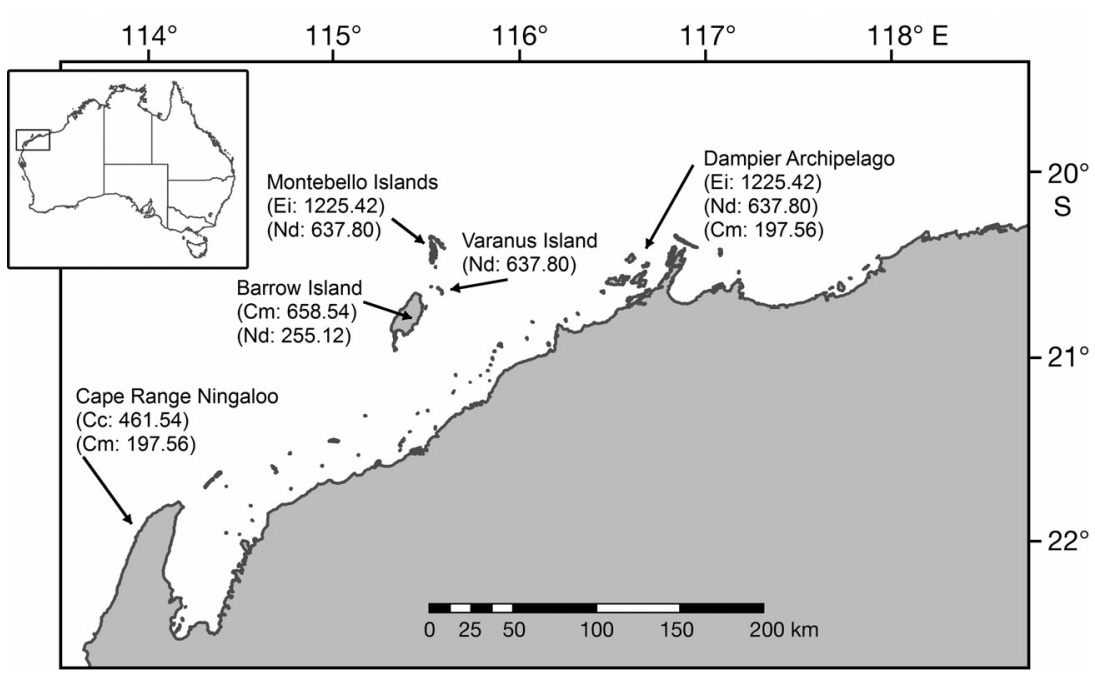

Fig. 2. The 10 nesting sites (by species) in Australia potentially at highest risk from maximum light exposure (maximum pixel values), with light pollution exposure values (percent nesting $\times$ risk value) in parentheses. Cc: loggerhead Caretta caretta; Cm: green Chelonia mydas; Ei: hawksbill Eretmochelys imbricata; Nd: flatback Natator depressus

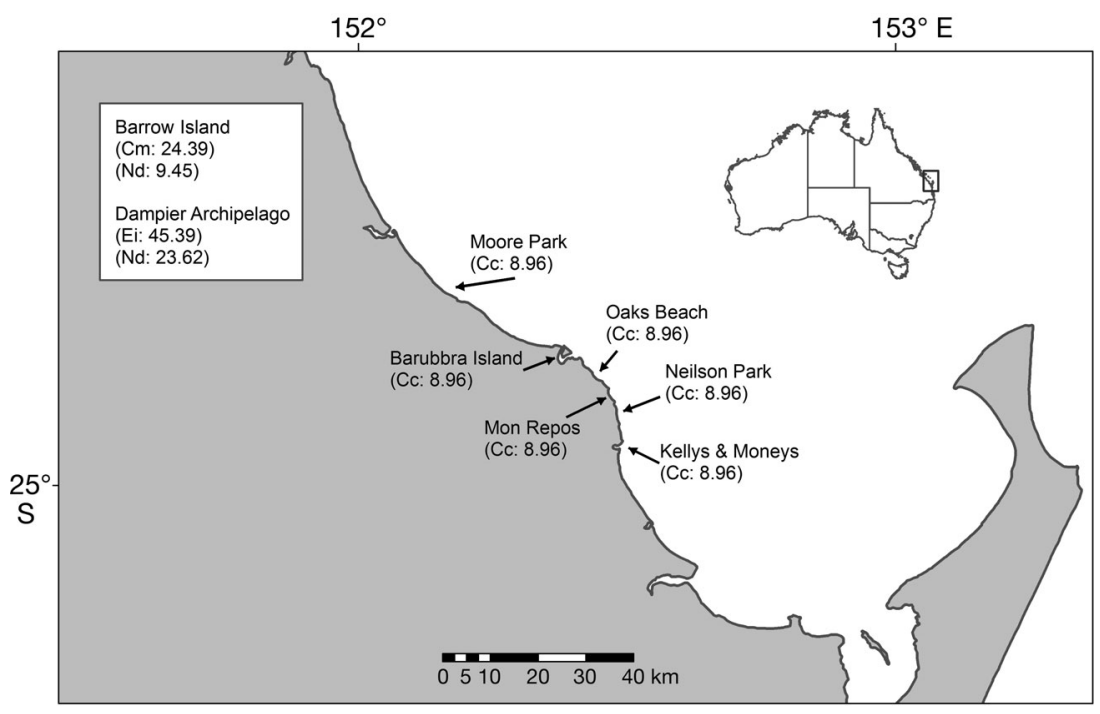

Fig. 3. The 10 nesting sites (by species) in Australia potentially at highest risk from mean light exposure (mean pixel values), with light pollution exposure values (percent nesting $\times$ risk value) in parentheses. Six of the sites occurred in SE QLD, 4 in WA (values inset left, see Fig. 2 for locations). Cc: loggerhead Caretta caretta; Cm: green Chelonia mydas; Ei: hawksbill Eretmochelys imbricata; Nd: flatback Natator depressus

nesting (Witherington \& Martin 2000). However, lights from very small residential settlements (populations of $<300$ people) in remote regions of Australia_including islands of the Torres Strait where no industry or commercial entities existwere picked up by the satellite data. Therefore, it is unlikely that significant sources of potentially disorienting light exist in Australia which were not identified in the present study.
Furthermore, an examination of our data in light of evidence regarding the beach-scale impact of light pollution in Australia supports the value of our methodology. We determined that nesting sites on the North West Shelf of WA and along the Woongarra coast of QLD were the sites facing the highest potential risk from light pollution Australia-wide, with nest sites in northern Australia appearing to be minimally exposed to light pollution. In his comprehensive review of marine turtles within Australia, Limpus (2009) evaluated the threat of light pollution for each species of turtle, using data and observations from researchers working on the ground. Reflecting our data, Limpus (2009) found no evidence of turtles disrupted by artificial light in northern Australia, but highlighted the Woongarra coast of QLD and the North West Shelf in WA as areas where disorientation of hatchlings regularly occurred due to the presence of artificial lights. Consequently, the method we have presented offers a useful means of highlighting particular regions, over a large spatial scale, where marine turtle nesting may be at risk from light pollution. Our method also allows for the magnitude of potential light pollution risk to be compared across nest sites. Once potentially high-risk sites for management units have been identified, the next step for managers should be an on-the-ground assessment to confirm the risk identified by the broad-scale analysis presented here, and to subsequently determine necessary beach-specific management actions.

Overall our findings indicate that there is large spatial variation in levels of coastal light pollution across Australia, which might be expected to cause disruption to marine turtles. Although the majority of marine turtle nesting in Australia appears to be minimally affected by light pollution, large proportions of nesting hawksbill, flatback, green and loggerhead turtles do appear to be exposed to light pollution, especially in WA and along the urban coast of Queensland. Moreover, turtles at these sites are potentially exposed to light sub- 
stantially brighter than natural night-time brightness, with most affected nesting sites potentially exposed to light pollution of Category 5 or higher $(>1$ to 3 times brighter than natural night-time brightness). This is important because ecological and behavioural studies have found that hatchling disorientation can be caused by very low levels of artificial light (Witherington \& Martin 2000). The pervasive levels of light pollution we found would be expected to disrupt turtle orientation at these sites.

Certain management units appear to face extreme potential risk, with $99.8 \%$ of hawksbill turtle nesting sites and $87.4 \%$ of flatback turtle nesting sites in WA determined to be at risk from light pollution. This is substantially higher than previous estimates of 12 and $42 \%$ for hawksbill and flatback turtles, respectively, in the region of the Barrow, Lowendal and Montebello Islands of WA (Pendoley 2005). However, where we calculated exposure within an area $25 \mathrm{~km}$ in radius from the nesting site, Pendoley (2005) considered the effect of lights within a radius of $1.5 \mathrm{~km}-$ a conservative radius considering the distance over which lights have been known to disrupt turtle behaviour on land (Hodge et al. 2007) and may potentially affect hatchling behaviour in the sea. Turtle hatchlings swim slowly, covering only $1.5 \mathrm{~km} \mathrm{~h}^{-1}$ or less (Frick 1976, Salmon \& Wyneken 1987). However, swimming hatchlings show oriented swimming behaviour for longer than $24 \mathrm{~h}$ (Salmon \& Wyneken 1987) and, in the absence of wave cues to guide them offshore, have been found to be more susceptible to disorientation from onshore light cues (Lorne \& Salmon 2007). Consequently, in the absence of wave cues, artificial lights may influence the orientation of swimming hatchlings over distances $>1.5 \mathrm{~km}$. The high proportion of hawksbill and flatback turtle nesting sites in WA identified as being at potential risk in the present study highlights the need for management and policy approaches that consider synergistic and cumulative impact.

We found that within Australia a few nesting sites in WA, which support nesting by multiple species, appear to be the sites most vulnerable to light pollution-namely the Dampier Archipelago, the Montebello Islands, Varanus Island and Barrow Island. The presence of light pollution at these sites is well known. This is one of WA's, and indeed Australia's, most productive regions for resource extraction, processing and shipping, with $59 \%$ of WA's oil and $93 \%$ of WA's gas being produced on the North West Shelf (Department of Environment and Conservation 2007). The influence of lights and flares from hydrocarbon industrial plants has been categorised as a current major pressure on turtles in this region (Pendoley 2000, Environment Australia 2003, Department of Environment and Conservation 2007, Environmental Protection Agency 2010), and State Government legislation, plus industry-specific management plans, are in place to regulate the of use of appropriate lighting by existing and future industry (Department of Environment and Conservation 2007, 2008, Chevron Australia 2009, Environmental Protection Agency 2010, BHP Billiton 2011).

Despite acknowledgement of the existence of light pollution in this region, we demonstrate that nest site exposure to light pollution may be far higher in WA than elsewhere in Australia, and, collectively, it could impact turtles at ecological scales, since multiple nesting sites appear affected within turtle management units. This indicates that rigorous light pollution management is vital, particularly given the importance of the turtle management units which nest here. The WA management units of hawksbill, green, loggerhead and flatback turtles are globally significant for their respective species (Seminoff 2002, Mortimer \& Donnelly 2008). Moreover, our results are conservative due to our use of light data from 2006; since that time development of the region has continued.

In 1 recent liquefied natural gas (LNG) development, the proponents were legally obliged under ministerial conditions attached to their Australian Government approval to develop management plans for marine turtles and develop and implement mitigation plans for light pollution. Under these plans, site-specific light pollution is audited annually (Chevron Australia 2009). Yet, although light pollution in this region seems to be being addressed by individual producers at site-specific scales (e.g. Sinclair Knight Merz 2008, Chevron Australia 2009, BHP Billiton 2011), the cumulative effect of extreme light levels over a small geographic region, or as it relates to specific turtle management units, is not addressed by State or Australian Government legislation or policy (Department of Environment and Conservation 2008)

We also found that nesting sites in eastern Australia appeared to be at high risk from light pollution, particularly in the case of loggerhead turtles along the Woongarra coast of south-east QLD. Interestingly these nesting locations were only identified as being at high potential risk when using the mean light exposure values, i.e. the mean pixel value within the $25 \mathrm{~km}$ buffer. This suggests that light pollution in eastern Australia may be characterised by areas of widespread, moderate levels of light pollution from dispersed urban settlements, as opposed to small 
areas of high levels of localised light pollution from intense industrial development on an otherwise relatively unsettled coastline in WA. This has implications for management in that it may be more economically and logistically feasible to implement light mitigation in WA, by targeting small areas of high light pollution produced by a limited number of contributors, rather than targeting a larger area producing moderate levels of light pollution, with multiple contributors (e.g. Fuentes et al. 2011).

Industrial development is increasing along the eastern Australian coast, as well as in other turtle nesting locations worldwide, including Qatar (Tayab \& Quiton 2003) and India (Fernandes 2008). Given the findings from the present study, which suggest that the amount of light pollution produced by similar existing industrial developments in WA may pose a very high risk to nesting marine turtles, the adequate management of light generated by proposed and ongoing industrial developments should be considered extremely important by managers and policy makers. One of the challenges currently faced by industry, regulators and researchers involved with turtle conservation is the lack of monitoring tools to examine low, ecologically relevant, light levels, or tools to test the effects of skyglow.

By virtue of the collection method, only night-time light levels on cloud-free nights are represented by the satellite data (Elvidge et al. 2001). A recent study has demonstrated that cloud cover substantially increases skyglow, since unused light escaping upwards into the atmosphere is reflected back down to Earth by clouds (Kyba et al. 2011). The authors argue that investigations into the ecological effects of light pollution need to take cloud coverage into consideration. Thus, light pollution levels and the subsequent impacts of this light at turtle nesting sites on cloudy nights may be even higher than suggested by our findings.

\section{CONCLUSIONS}

Light pollution is an indisputable problem for marine turtles, and, given existing and continuing coastal development along many of the world's turtle nesting beaches, it is also likely to be a pervasive issue. Studies investigating the impacts of light pollution on marine turtles are numerous; yet, since most of this research is beach or region specific, understanding the risks posed to breeding marine turtles at a management unit scale, from light generated by different producers, has not been possible.
Our study is the first of its kind. The methodology we present provides a useful first step for effectively managing the disruptive influence of light pollution on marine turtles, at an ecologically relevant scale. The large spatial scale we used emphasises the significant risk that concentrated light produced by industrial developments, and diffuse light generated by urban complexes, may pose to nesting marine turtles. We also highlight the regions of Australia where turtle nesting appears to be at highest risk from light pollution, namely southerly nesting sites on both the west and east coasts, with sites in northern Australia least affected.

In view of the multitude of threats faced by turtles, consideration of this information is extremely relevant for managers, especially in regions of planned industrial development. This is particularly important in regions with multiple contributors to artificial light production, since cumulative light levels may not be addressed in management plans. Furthermore, the identification of concentrated and diffuse light pollution indicates that management strategies may need to be tailored depending on the sources generating the artificial light.

We recommend that light-mitigation strategies be implemented as standard as development increases along the Australian coastline, and we urge managers of marine turtles elsewhere to recognise the huge potential for disruption that light generated by industrial and urban developments may cause.

Acknowledgements. We thank SEQ Catchments and QDERM for providing the nesting data, P. Whittock for information on nest sites in WA, P. Ridd for advice regarding the conversion of light from radiance to luminance values and D. Ziskin at NOAA for assistance with the night-light data files. We also thank J. Hazel for useful comments, and A. Edwards for help with the figures. Advice from 2 anonymous reviewers greatly improved the manuscript. We acknowledge the image and data processing of night-light data by NOAA's National Geophysical Data Center and the DMSP data collected by the US Air Force Weather Agency. This manuscript forms part of R.L.K.'s PhD research at James Cook University. R.L.K. is supported by the Northcote Trust Graduate Scholarship Scheme.

\section{LITERATURE CITED}

Aubrecht C, Elvidge CD, Eakin CM (2008) Earth observation based assessment of anthropogenic stress to coral reefs - a global analysis. Proc 2008 IGARRS 4:367-370

Aubrecht C, Jaiteh M, de Sherbinin A (2010) Global assessment of light pollution impact on protected areas. CIESIN/AIT Working Paper, Columbia University, New York, NY. Available at www.ciesin.columbia.edu/ publications.html 
Australian Bureau of Statistics (2012) Regional population growth, Australia, 2009-2012. Report 3218.0, Australian Bureau of Statistics, Canberra

Badarinath KVS, Sharma AR, Kharol SK (2011) Forest fire monitoring and burnt area mapping using satellite data: a study over the forest region of Kerala State, India. Int J Remote Sens 32:85-102

Bertolotti L, Salmon M (2005) Do embedded roadway lights protect sea turtles? Environ Manag 36:702-710

Beyer HL (2004) Hawth's analysis tools for ArcGIS. Available at www.spatialecology.com/htools (accessed 22 Feb 2011)

BHP Billiton (2011) Marine turtle management plan. Available at www.bhpbilliton.com/home/aboutus/regulatory/ Documents/perAppendixA1MarineTurtleManagement Plan.pdf (accessed 2 Nov 2011)

Bird BL, Branch LC, Miller DL (2004) Effects of coastal lighting on foraging behavior of beach mice. Conserv Biol 18: 1435-1439

Booth DT, Evans A (2011) Warm water and cool nests are best. How global warming might influence hatchling green turtle swimming performance. PLoS ONE 6:e23162

> Bowen BW, Meylan AB, Ross JP, Limpus CJ, Balazs GH, Avise JC (1992) Global population structure and natural history of the green turtle (Chelonia mydas) in terms of matriarchal phylogeny. Evolution 46:865-881

Broderick D, Moritz C, Miller J, Guinea M, Prince R, Limpus C (1994) Genetic studies of the hawksbill turtle Eretmochelys imbricata: evidence for multiple stocks in Australian waters. Pac Conserv Biol 1:123-131

Bustard HR, Tognetti KP (1969) Green sea turtles: a discrete simulation of density-dependent population regulation. Science 163:939-941

Chalkias C, Petrakis M, Psiloglou B, Lianou M (2006) Modelling of light pollution in suburban areas using remotely sensed imagery and GIS. J Environ Manag 79:57-63

Chatto R, Baker B (2008) The distribution and status of marine turtle nesting in the Northern Territory. Parks and Wildlife Service of the NT, Palmerston

Chevron Australia (2009) Gorgon gas development and Jansz feed gas pipeline long-term marine turtle management plan G1-NT-PLNX0000296, Chevron Australia Pty Ltd. Available at www.chevronaustralia.com/Libraries/ Chevron_Documents/Gorgon_Long-term_Marine_Turtle _Management_Plan.pdf.sflb.ashx (accessed 4 November 2011)

CIE (International Commission on Illumination) (1932) Receuil des travaux et compte rendue des scéances, huitième session Cambridge-Septembre 1931. Cambridge University Press, Cambridge

> Cinzano P, Falchi F, Elvidge CD (2001a) The first World Atlas of the artificial night sky brightness. Mon Not $\mathrm{R}$ Astron Soc 328:689-707

Cinzano P, Falchi F, Elvidge CD (2001b) Naked eye star visibility and limiting magnitude mapped from DMSP-OLS satellite data. Mon Not R Astron Soc 323:34-46

Conant TA, Dutton PH, Eguchi T, Epperly SP and others (2009) Loggerhead sea turtle (Caretta caretta) 2009 status review under the US Endangered Species Act. Report of the loggerhead biological review team. National Marine Fisheries Service, Silver Spring, MD

Department of Environment and Conservation (2007) Management plan for the Montebello/Barrow Islands marine conservation reserves, 2007-2017. Department of Environment and Conservation, Perth
Department of Environment and Conservation (2008) Draft marine turtle recovery plan for Western Australia. In: Western Australian wildlife management program. Department of Environment and Conservation, Perth

> Dethmers KEM, Broderick D, Moritz C, Fitzsimmons NN and others (2006) The genetic structure of Australasian green turtles (Chelonia mydas): exploring the geographical scale of genetic exchange. Mol Ecol 15:3931-3946

Dobbs K, Miller J, Limpus C, Landry A Jr (1999) Hawksbill turtle, Eretmochelys imbricata, nesting at Milman Island, northern Great Barrier Reef, Australia. Chelonian Conserv Biol 3:344-361

Dunn OJ (1964) Multiple comparisons using rank sums. Technometrics 6:241-252

> Elvidge CD, Baugh KE, Hobson VR, Kihn EA, Kroehl HW, Davis ER, Cocero D (1997) Satellite inventory of human settlements using nocturnal radiation emissions: a contribution for the global toolchest. Glob Change Biol 3: 387-395

Elvidge CD, Imhoff ML, Baugh KE, Hobson VR and others (2001) Night-time lights of the world: 1994-1995. ISPRS J Photogramm Remote Sens 56:81-99

> Elvidge CD, Cinzano P, Pettit DR, Arvesen J and others (2007) The Nightsat mission concept. Int J Remote Sens 28:2645-2670

Environment Australia (2003) Recovery plan for marine turtles in Australia. Environment Australia Marine Species Section, Canberra

Environmental Protection Agency (2010) Environmental assessment guideline for protecting marine turtles from light impacts, No. 5. Environmental Protection Agency, Perth

Fernandes A (2008) IUCN-TATA partnership - undermining conservation. Mar Turtle Newsl 121:20-21

Frick J (1976) Orientation and behaviour of hatchling green turtles (Chelonia mydas) in the sea. Anim Behav 24: 849-857

> Fuentes MMPB, Maynard JA, Guinea M, Bell IP, Werdell PJ, Hamann M (2009) Proxy indicators of sand temperature help project impacts of global warming on sea turtles in northern Australia. Endang Species Res 9:33-40

Fuentes M, Limpus C, Hamann M (2011) Vulnerability of sea turtle nesting grounds to climate change. Glob Change Biol 17:140-153

Garstang RH (1986) Model for artificial night-sky illumination. Publ Astron Soc Pac 98:364-375

Gyuris E (1993) Factors that control the emergence of green turtle hatchlings from the nest. Wildl Res 20:345-353

Hamann M, Jessop TS, Schäuble CS (2007) Fuel use and corticosterone dynamics in hatchling green sea turtles (Chelonia mydas) during natal dispersal. J Exp Mar Biol Ecol 353:13-21

> Hamann M, Grech A, Wolanski E, Lambrechts J (2011) Modelling the fate of marine turtle hatchlings. Ecol Model 222:1515-1521

> Harewood A, Horrocks J (2008) Impacts of coastal development on hawksbill hatchling survival and swimming success during the initial offshore migration. Biol Conserv 141:394-401

Hennessy K, Fitzharris B, Bates BC, Harvey N and others (2007) Australia and New Zealand. In: Parry ML, Canziani OF, Palutikof JP, van der Linden PJ, Hanson CE (eds) Climate change 2007: impacts, adaptation and vulnerability. Contribution of Working Group II to the 4th assessment report of the Intergovernmental Panel on Cli- 
mate Change. Cambridge University Press, Cambridge, p 507-540

Hentschel HJ (1994) Licht und Beleuchtung: Theorie und Praxis der Lichttechnik, 4. Auflage. Hüthig, Heidelberg

Heppell SS, Snover ML, Crowder LB (2003) Sea turtle population ecology. In: Lutz PL, Musick JA, Wyneken J (eds) The biology of sea turtles. CRC Press, Boca Raton, FL, p 275-306

Hodge W, Limpus CJ, Smissen P (2007) Queensland turtle conservation project: Hummock Hill Island nesting turtle study December 2006. In: Conservation technical and data report. Environmental Protection Agency, Brisbane, p 1-10

Horch KW, Gocke JP, Salmon M, Forward RB (2008) Visual spectral sensitivity of hatchling loggerhead (Caretta caretta L.) and leatherback (Dermochelys coriacea L.) sea turtles, as determined by single-flash electroretinography. Mar Freshw Behav Physiol 41:107-119

Kramer KM, Birney EC (2001) Effect of light intensity on activity patterns of Patagonian leaf-eared mice, Phyllotis xanthopygus. J Mammal 82:535-544

Kyba CCM, Ruhtz T, Fischer J, Holker F (2011) Cloud coverage acts as an amplifier for ecological light pollution in urban ecosystems. PloS ONE 6:e17307

> Levenson DH, Eckert SA, Crognale MA, Deegan JF II, Jacobs GH (2004) Photopic spectral sensitivity of green and loggerhead sea turtles. Copeia 2004:908-914

Limpus C (1971) The flatback turtle, Chelonia depressa Garman in southeast Queensland, Australia. Herpetologica $27: 431-446$

Limpus C (2009) A biological review of Australian marine turtles. Environmental Protection Agency, Brisbane

Limpus C, Miller J, Paramenter C, Reimer D, McLachlan N, Webb R (1992) Migration of green (Chelonia mydas) and loggerhead (Caretta caretta) turtles to and from eastern Australian rookeries. Wildl Res 19:347-357

Limpus C, Miller J, Chatto R (2000) Distribution and abundance of marine turtle nesting in northern and eastern Australia. In: Final report for Australian hawksbill turtle population dynamics project. Queensland Parks and Wildlife Service, Brisbane, p 19-37

Lorne JK, Salmon M (2007) Effects of exposure to artificial lighting on orientation of hatchling sea turtles on the beach and in the ocean. Endang Species Res 3:23-30

Luck GW (2007) The relationships between net primary productivity, human population density and species conservation. J Biogeogr 34:201-212

Magyar T (2008) The impact of artificial lights and anthropogenic noise on loggerheads (Caretta caretta) and green turtles (Chelonia mydas), assessed at index nesting beaches in Turkey and Mexico. PhD thesis, University of Bonn

Mortimer J, Donnelly M (2008) Marine Turtle Specialist Group 2007 IUCN Red List status assessment, hawksbill turtle (Eretmochelys imbricata). IUCN, Marine Turtle Specialist Group, Gland

Nagatani I (2010) A methodology to create DMSP-OLS night-time mosaic image for monitoring fishing boats. Proc 30th Asia-Pacific advanced network meeting, Dec 2010, p 143-152. Available at: http://apan.upm.edu.my/ DMSP/APAN_31_Nagatani.pdf (accessed 16 Apr 2011)

Narisada K, Schreuder D (2004) Light pollution handbook. Springer, Dordrecht

National Geophysical Data Centre (2006) Global radiance calibrated nighttime lights. NOAA, Washington, DC
Nicholls RJ (1995) Coastal megacities and climate change. GeoJournal 37:369-379

Palmer JM (1999) Radiometry and photometry FAQ. Available at: http://employeepages.scad.edu/ kwitte/ documents/Photometry_FAQ.PDF (accessed 23 Jun 2011)

Pendoley K (2000) The influence of gas flares on the orientation of green turtle hatchlings at Thevenard Island, Western Australia. In: Pilcher N, Ghazally I (eds) Proc 2nd ASEAN symposium and workshop on sea turtle biology and conservation. ASEAN Academic Press, Kotal Kinabalu, p 130-142

Pendoley K (2005) Sea turtles and the environmental management of industrial activities in north west Western Australia. Murdoch University, Perth

> Peters A, Verhoeven KJF (1994) Impact of artificial lighting on the seaward orientation of hatchling loggerhead turtles. J Herpetol 28:112-114

Pilcher NJ, Enderby S, Stringell T, Bateman L (2000) Nearshore turtle hatchling distribution and predation in Sabah, Malaysia. In: Kalb H, Wibbels T (eds) Proc 19th annual sea turtle symposium. NOAA Tech Mem NMFSSEFSC 443: 27-29

Putman NF, Bane JM, Lohmann KJ (2010) Sea turtle nesting distributions and oceanographic constraints on hatchling migration. Proc Biol Sci 277:3631-3637

Rich C, Longcore T (2006) Ecological consequences of artificial night lighting. Island Press, Washington, DC

Rodrigues P, Aubrecht C, Gil A, Longcore T, Elvidge C (2012) Remote sensing to map influence of light pollution on Cory's shearwater in São Miguel Island, Azores Archipelago. Eur J Wildl Res 58:147-155

Salmon M (2003) Artificial night lighting and sea turtles. Biologist 50:163-168

Salmon M (2006) Protecting sea turtles from artificial night lighting at Florida's oceanic beaches. In: Rich C, Longcore $\mathrm{T}$ (eds) Ecological consequences of artificial night lighting. Island Press, Washington, DC

Salmon M, Witherington B (1995) Artificial lighting and seafinding by loggerhead hatchlings: evidence for lunar modulation. Copeia 1995:931-938

Salmon M, Wyneken J (1987) Orientation and swimming behaviour of hatchling loggerhead sea turtles (Caretta caretta L.) during their offshore migration. J Exp Mar Biol Ecol 109:137-153

Salmon M, Witherington BE, Elvidge CD (2000) Artificial lighting and the recovery of sea turtles. In: Pilcher $N$, Ismail G (eds) Sea turtles of the Indo-Pacific: research, management and conservation. ASEAN Academic Press, London, p 25-34

Seminoff J (2002) IUCN Red List global status assessment, green turtle Chelonia mydas. IUCN Marine Turtle Specialist Group Review, IUCN, Gland

SEQ Catchments (2010) Summary report on: managing what matters, the cost of environmental decline in south east Queensland. SEQ Catchments Ltd, Brisbane

Smith FG (1979) Report and recommendations of IAU Commission 50, Reports on Astronomy. Int Astronom Union Trans A, XVIIA:218-222

Sinclair Knight Merz (2008) Pluto LNG development sea turtle management plan. Project No. WV03424.010. Woodside Energy Ltd, Perth

Stapput K, Wiltschko W (2005) The sea-finding behavior of hatchling olive ridley sea turtles, Lepidochelys olivacea, at the beach of San Miguel (Costa Rica). Naturwissenschaften 92:250-253 
Steck TL, Bartelmus P, Sharma A (2010) Human population explosion. In: Cleveland CJ (ed) Encyclopedia of Earth. Environmental Information Coalition, National Council for Science and the Environment, Washington, DC. Available at: www.eoearth.org/article/Human_population _explosion?topic=54245 (accessed 27 Mar 2011)

Tayab MR, Quiton P (2003) Marine turtle conservation initiatives at Ras Laffan Industrial City, Qatar (Arabian Gulf). Mar Turtle Newsl 99:14-15

> Troëng S, Rankin E (2005) Long-term conservation efforts contribute to positive green turtle Chelonia mydas nesting trend at Tortuguero, Costa Rica. Biol Conserv 121: 111-116

Tuxbury SM, Salmon M (2005) Competitive interactions between artificial lighting and natural cues during seafinding by hatchling marine turtles. Biol Conserv 121: 311-316

Wallace BP, DiMatteo AD, Hurley BJ, Finkbeiner EM and others (2010) Regional management units for marine turtles: a novel framework for prioritizing conservation and research across multiple scales. PLoS ONE 5:e15465

Witherington B (1991) Orientation of hatchling loggerhead turtles at sea off artificially lighted and dark beaches. J

Editorial responsibility: Brendan Godley,

University of Exeter, Cornwall Campus, UK
Exp Mar Biol Ecol 149:1-11

Witherington B, Bjorndal KA (1991) Influences of wavelength and intensity on hatchling sea turtle phototaxis: implications for sea-finding behavior. Copeia 1991: 1060-1069

Witherington B, Martin RE (2000) Understanding, assessing, and resolving light-pollution problems on sea turtle nesting beaches, 2nd edn., rev. Tech Rep TR-2. Florida Fish and Wildlife Conservation Commission, Marine Research Institute, St. Petersburg, FL, p 1-73

Wyneken J, Salmon M, Fisher L, Weege S (2000) Managing relocated sea turtle nests in open beach hatcheries. Lessons in hatchery design and implementation in Hillsboro Beach, Broward County, Florida. In: Kalb H, Wibbels T (eds) Proc 19th annual sea turtle symposium. NOAA Tech Mem NMFS-SEFSC 443:193-194

Ziskin D, Aubrecht C, Elvidge CD, Tuttle B, Baugh KE, Ghosh T (2008) Encroachment of human activity on sea turtle nesting sites. In: Proceedings of the rall meeting 2008. American Geophysical Union, Washington, DC, p 361

Zissis G, Ruscassie R, Aubes M (2007) The quest of the perfect light source. Ing Iluminatului 9:71-78

Submitted: June 14, 2012; Accepted: September 4, 2012

Proofs received from author(s): November 21, 2012 